\title{
Envisioning the challenges of the pharmaceutical sector in the Indian health-care industry: a scenario analysis
}

\author{
Giuseppe Festa \\ Department of Economics and Statistics, University of Salerno, Fisciano, Italy \\ Ashutosh Kolte \\ Department of Management Sciences (PUMBA), Savitribai Phule Pune University, Pune, India \\ Maria Rosaria Carli \\ Institute for Studies on the Mediterranean (ISMed), Italian National Research Council (CNR), Naples, Italy, and \\ Matteo Rossi \\ Department of Law Economics Management and Quantitative Methods, University of Sannio, Benevento, Italy and \\ Wyższa Szkoła Bankowa w Poznaniu - WSB University, Poznan, Poland
}

\begin{abstract}
Purpose - This study aims to access, analyze and highlight opportunities and problems of the Indian pharmaceutical sector in the broader national health-care industry. The recent changes in the field, at the institutional and corporate levels, have placed India in the spotlight of the global pharmaceutical market, but several threats and weaknesses could limit this expansion.

Design/methodology/approach - Descriptive and inferential analyses have been based on empirical data extracted from authenticated data sources. Subsequently, a narrative strengths, weaknesses, opportunities and threats analysis was performed based on the results of prior investigations and on qualitative data that were retrieved from a marketing intelligence examination to generate an overall scenario analysis.

Findings - Indian pharmaceutical companies have faced several challenges on various fronts. In the home market, drug prices are controlled by the drug price control order; therefore, there is strong pressure on revenues and subsequently on costs. In the international market, threats derived from pharmaceutical multinational companies are emerging as tough obstacles to overcome.

Practical implications - More focus on patents for innovative drugs is required, instead of concentrating primarily on generic drugs. There is a need for policymakers to work on the sustainability and development of the industry, while the companies must redesign their orientation toward enhancing innovation capabilities. In addition, at the level of corporate strategy, firms should establish collaborations and alliances and expand their industrial marketing vision.

Originality/value - This study provides a global overview of the potential growth and development of the Indian pharmaceutical sector, comparing it with internal trends and external competition. The most relevant contribution of the research relies on the shift to innovative production that Indian companies must adopt (after years of focusing only on generic drugs), and in this vein, appropriate industrial marketing solutions are indispensable.
\end{abstract}

Keywords India, Intellectual property, Health-care industry, Pharmaceutical sector, Marketing innovation, Production innovation

Paper type Research paper

\section{Introduction}

The Indian pharmaceutical sector is at the top among the country's science-based industries, having widespread competencies in the complex field of drug manufacturing and technology; prior to 1991, governmental policies focused on self-reliance, protectionism and lesser cooperation in trade and services, whereas the world was advancing technologically very quickly, particularly in the information technology sector (Sharma, 2016; Kraus et al., 2021). These factors affected the

The current issue and full text archive of this journal is available on Emerald Insight at: https://www.emerald.com/insight/0885-8624.htm

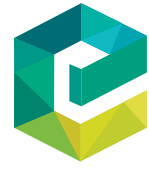

Journal of Business \& Industrial Marketing 37/8 (2022) 1662-1674

Emerald Publishing Limited [ISSN 0885-8624] [DOI 10.1108/JBIM-07-2020-0365]
(C) Giuseppe Festa, Ashutosh Kolte, Maria Rosaria Carli and Matteo Rossi. This paper is the result of the common reflection of all the authors. In the editing phase, the 'Introduction', 'Research objectives and methodology', 'Results' (excluding the 'The scenario of the Indian pharmaceutical industry: descriptive and inferential analysis' and the 'The scenario of the Indian pharmaceutical industry: contextual analysis' subsections), 'Research limitations and future directions', and the 'Conclusion' sections were written by Giuseppe Festa. The 'The scenario of the Indian pharmaceutical industry: contextual analysis' and the 'A narrative strengths, weaknesses, opportunities and threats analysis of the Indian pharmaceutical industry' sections were written by Ashutosh Kolte. The 'Institutional and scientific background' section was written by Maria Rosaria Carli. The 'The scenario of the Indian pharmaceutical industry: descriptive and inferential analysis' and the 'Theoretical and practical implications' sections were written by Matteo Rossi. Published by Emerald Publishing Limited. This article is published under the Creative Commons Attribution (CC BY 4.0) licence. Anyone may reproduce, distribute, translate and create derivative works of this article (for both commercial \& non-commercial purposes), subject to full attribution to the original publication and authors. The full terms of this licence may be seen at http://creativecommons.org/licences/by/4.0/legalcode

Received 29 July 2020

Revised 18 January 2021

30 January 2021

8 May 2021

Accepted 10 May 2021 
country in many ways; one of the most relevant impacts was less priority given to the health sector for growth and modernization, with smaller cities and remote areas covered with the inefficient national health-care service or small hospitals and practitioners (Abrol et al., 2011).

The subsequent development of the sector brought India to rank among the top health-care markets in the world by the end of 2020. Various factors have influenced this progress: an increase in per capita income, boosting public awareness of various diseases and preventive measures, decreasing costs of health-care services, effective research and development (R\&D) activities and governmental policies to induce foreign investment (IBEF, 2016).

From a quantitative point of view, the Indian health-care sector is expected to surpass US $\$ 372$ bn by 2022 and by 2024-2025, India's biotech industry is estimated to increase to US\$100bn (FICCI, 2018). From a qualitative point of view, the Indian health-care sector focuses on several critical pillars: preventive health care, accessible health care, building medical services and mission style strategies for maternal health, child health and the marked rise in the burden to fight transmissible and noncommunicable diseases (Venkatesh et al., 2019).

Although its economy is the third-largest in the world after China and the USA in terms of purchasing power parity (Imf.org), India is still characterized by insufficient health-care facilities, scarce physical and medical infrastructure, and insufficient specialized medical staff in smaller cities and rural areas, largely due to a lack of economic resources (Roy et al., 2019).

The Indian pharmaceutical industry is among the top producers in the world, supplying over $50 \%$ of the global demand for various vaccines, $40 \%$ of generic demand in the USA and $25 \%$ of all medicines in the UK (IBEF, 2020). Although the sector still shows more relevant values concerning production quantity than production turnover, pharmaceutical exports are expected to reach US $\$ 16.28$ bn in FY20 (ibidem).

Presently, there are more than 11,000 manufacturing units and over 3,000 pharma companies in India; although the industry is growing at an exceptional rate, it is highly fragmented; the top ten firms, including multinational companies (MNCs), account for only one-third of the total revenues from the sector (Gulaldavar, 2019). The market is dominated by generic products with $71 \%$ of the total market share and $20 \%$ of global exports in terms of volume, which makes India the largest supplier of generics globally (IBEF, 2016), with particular importance in the field of vaccines (Chattopadhyay and Bercovitz, 2020).

In this study, we tried to identify and analyze the current situation of the Indian pharmaceutical industry, attempting to track the marketing trajectories of the industry and emphasizing possibilities and opportunities for healthy growth and development at the domestic and international levels. The remainder of the paper is organized as follows: after a global overview of the industrial scenario, with specific attention paid to industrial marketing dynamics, a descriptive and inferential analysis has been developed that provides adequate information about trends in production and trade balance; subsequently, a content analysis and a narrative strengths, weaknesses, opportunities and threats (SWOT) analysis contribute to delineating a global scenario analysis intended as a fundamental instrument of industrial strategic marketing (de Kluyver, 1980; Pinchot, 2001; Kirchgeorg et al., 2010; Ha and Nam, 2016; Lew et al., 2019); the paper concludes with considerations of its theoretical and practical implications.

\section{Institutional and scientific background}

The Indian pharmaceutical sector has been interested in achieving a huge expansion in the last decade, although it is exceedingly uneven with more than 20,000 registered units; the sector meets approximately $70 \%$ of the country's demand, consisting of a highly fragmented market, and has seen increased price competition and governmental price control; consequently, the companies in the field show huge differences in innovative capabilities, and they can be grouped into three types innovators, niche operators and manufacturers - each showing the need for different innovation policies to sustain their growth and development (Sampath, 2006). From an industrial marketing perspective, the most relevant aspect of the Indian pharmaceutical industry is that it is in a process of transformation, seeking to gain even more credibility at the national and international levels and particularly with the government that is implementing the new compliant intellectual property regime (Prakash et al., 2018).

The current regulations are not yet designed to promote patent filings (Chaudhuri, 2019), and this situation strongly impacts the internationalization perspective. The Indian pharmaceutical industry has been facing problems such as declining exports and increasing prices in many instances and maintaining competitiveness and market share in this sector depends on the firms' ability to obtain patents (Tyagi et al., 2018), requiring substantial spending in $\mathrm{R} \& \mathrm{D}$ and knowledge building (Tyagi and Nauriyal, 2017).

The Indian government has provided several policies to support the marketing impact of the industry; although tax-related benefits would be useful in this regard (Abbott, 2017; Gautam and Sharma, 2019), the measure of most impact would be to recognize intellectual property rights (IPRs) as the natural factor for encouraging pharmaceutical R\&D. From a financial point of view, a potential increase in working capital (tax benefits as deferred liquidity, for example) may improve the future performance of domestic companies (Vijayalakshmi and Srividya, 2015), but to maximize their enterprise value, there is a need for higher R\&D investments and major production of costeffective drugs, which are inevitably influenced by the financial structure of firms (Desai and Desai, 2018), with the current ratio that has a positive influence on $R \& D$ investment and the debt ratio that has a negative influence on R\&D investment (Lee and Choi, 2015).

The analysis of market access (MA) for ethical drugs shows the fundamental public-private interaction among pharmaceutical firms and public stakeholders to generate effects on health system stability (Santos et al., 2019); institutional and industrial collaborations are essential for understanding the modalities through which to achieve health system sustainability (Schiavone and Simoni, 2019; Guercini et al., 2020). Moreover, considering that the public side sometimes, or often, neglects the private business setting's interactivity and interdependence, it is desirable to promote the involvement of independent actors capable of delivering business reactivity, cost efficiency and quality control while being subject to competitive pressures (Waluszewski et al., 2019).

An additional aspect of the national industry, directly associated with IPRs, concerns secondary patents, often 
adopted to extend the periods, which is a concern for competitors and for governments; in response, several countries have provided specific measures to control the granting of these patents, but they were ineffective in many ways, revealing that it is vital to have a monitoring function to evaluate the effects of these applications in developing countries particularly (Sampat and Shadlen, 2017). In addition, it was realized that the dynamics enabling strategic account management in the pharmaceutical industry can emerge as an interaction model of value cocreation selling, suggesting the presence, in the hospital-pharmaceutical connection (Lepore et al., 2018; Zhang et al., 2018), of two key dimensions that may allow for customer-specific value-added initiatives and relationship enhancers (Pilon and Hadjielias, 2017).

The question about patents concerns not only the business perspective but also the social perspective, considering that the major problems of the Indian health-care industry - and secondarily the pharmaceutical industry - are accessibility and affordability; increased purchasing power and epidemiological changes are expected to spur dramatic growth in pharmacy sales volumes, but India remains a price-sensitive market (Devarakonda, 2016). These companies are forced to deal with many challenges not only in the home country but also abroad (for example, obtaining approval from the local authorities for the innovative drug business), having problems with the availability of good affordable medicines for patients (Bains et al., 2010), mainly at the economic level domestically and at the innovative level internationally.

The Defense of India Act included price control orders that first initiated price controls over drugs in 1963 (Wankhar, 2015). The MNCs had great dominance over the sector during that period, and therefore price controls came to be considered; they were pioneers in the supply of drugs and they sold all types of medicines at a higher rate as there was no control over the prices, with many people being unable to buy such expensive drugs for the treatment of various ailments: henceforth, under Section 3 of the Essential Commodities Act of 1955, the Drug Price Control Order (DPCO) was formulated and later introduced in India in 1995 (Singh, 2017) to guarantee major access to health care for larger portions of the population due to different economic conditions.

In fact, according to the World Health Organization (WHO. int), spending on health-care varies to a large extent in developing countries, transient economies and developed countries; developing nations spend $25 \%-66 \%$ on health care, while in transitional economies, nearly $15 \%-30 \%$ of money is spent on health care and associated activities. Paradoxically, but understandably, expenditures on pharmaceuticals and related products are relatively high in low-income countries; for example, India is said to be the country with the highest out-ofpocket expenditure in the health-care sector, largely because, according to the WHO, $65 \%$ of Indians are still unable to obtain the necessary medicines; there is a major tendency among Indian doctors to prescribe leading brands instead of cheaper alternatives; hence, there is an urgent need to make drugs accessible at more affordable prices (Nalinakanthi, 2014).

Finally, in a global consideration, poverty must be considered as one of the most important aspects of the Indian pharmaceutical market, most of all as concerns price control; approximately $42 \%$ of India's population lives below the poverty line, and more generally, South Asia has low per capita income; from this point of view, because of the ever-increasing population, the government cannot adequately support the pharmaceutical sector from a strict business perspective, having in mind the affordability of medicines and, ultimately, people's health (Parasiya et al., 2013). Thus, the Indian pharmaceutical sector seems to register two contrasting conditions: on the one hand, the impetuous evolution of the offer (with all the limitations concerning IPRs) and on the other hand, the inevitability of taking into careful consideration the economic situation of the demand, with the Indian population still unable to access health-care and medicine when necessary; in the face of this incongruity, which is nothing new in emerging countries, there are huge opportunities envisioned for the evolution of the Indian pharmaceutical industry, the theoretical and practical foundation for this research study, particularly in light of the COVID-19 pandemic, which has highlighted even more the indispensable economic and social value of the pharmaceutical supply chain.

\section{Research objectives and methodology}

Based on the above background, the following research questions have been formulated regarding the Indian pharmaceutical sector.

$R Q 1$. "Are the expectations about the global value of the industry positive or negative?"

RQ2. "Are the expectations about the trade balance positive or negative?"

RQ3. "What are the most relevant SWOT for the future?"

These objectives of the investigation highlight the essential explorative nature of the study, which has been finalized as a scenario analysis, adopting a mixed approach of quantitative and qualitative methods. To empirically carry out the investigation, secondary data have been extracted from the authenticated databases of the Centre for Monitoring Indian Economy (Cmie. com) and the Reserve Bank of India (Rbi.org.in), particularly to respond to $R Q 1$ and $R Q 2$. After determining the most relevant coordinates of the field, specific reports and issues from other governmental and corporate institutions have been purposively retrieved and analyzed through a content analysis for generating a narrative SWOT analysis, particularly to respond to $R Q 3$.

\section{Results}

The following investigation provides general elements for the examination of the current and expected scenarios of the Indian pharmaceutical sector to respond to $R Q 1$ and $R Q 2$. More specific data have been provided with reference to DPCO to respond to $R Q 3$.

\subsection{The scenario of the Indian pharmaceutical industry: descriptive and inferential analysis}

In value terms, the sector, considering the total manufacturing of pharmaceuticals, medicinal chemicals and botanicals (Table 1), is worth Rs. $145,841.1 \mathrm{~m}$ in 2018-2019. The largest market share concerns ayurvedic and homeopathic medicaments (AYUSH medicines) with $24.37 \%$, followed by antibiotics (API and formulations) with $18.82 \%$, and anti-retroviral drugs for 
Table 1 Production of pharmaceuticals, medicinal chemicals and botanicals

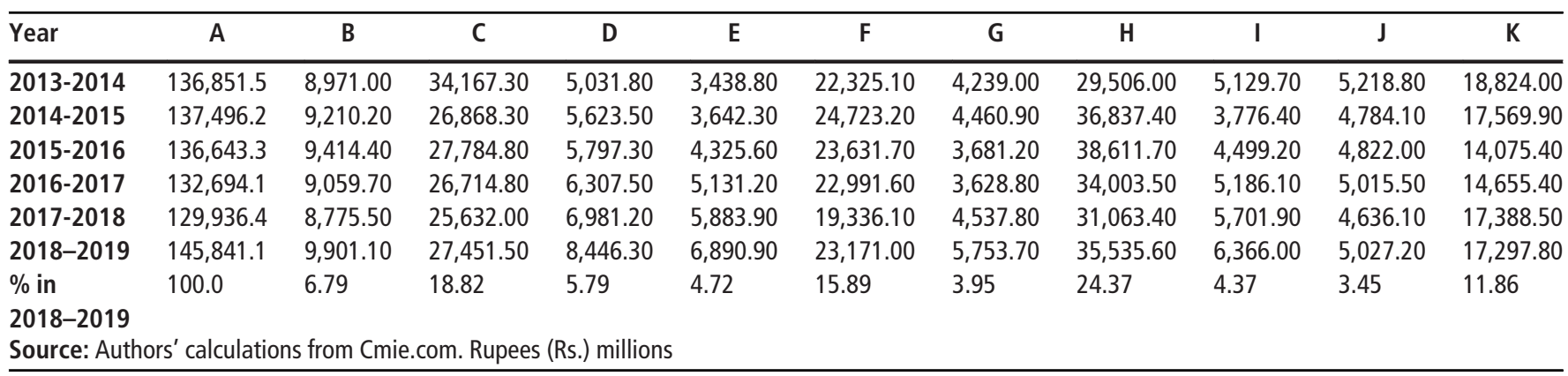

HIV (Human Immunodeficiency Virus) treatment with $15.89 \%$. These three pharmaceutical categories alone are worth approximately $60 \%$ of the entire Indian pharmaceutical production. In the above, API stands for Active Pharmaceutical Ingredient and AYUSH stands for Ayurveda, Yoga, Unani, Siddha and Homeopathy. Starting in 2014 in India, a Ministry of AYUSH was established, indicating the extraordinary relevance in the country of these specific items. In Table 1 , the following notation has been adopted.

$\mathrm{A}=$ Total production of pharmaceuticals, medicinal chemicals and botanical products

$\mathrm{B}=$ Vitamins (API and formulations)

$\mathrm{C}=$ Antibiotics (API and formulations)

$\mathrm{D}=$ Antidiabetic drugs (excluding insulin)

$\mathrm{E}=$ Antipyretic, analgesic/anti-inflammatory drugs (API and formulations)

$\mathrm{F}=$ Anti-retroviral drugs for HIV treatment

$\mathrm{G}=$ Capsules

$\mathrm{H}=$ Ayurvedic and homeopathic medicaments (AYUSH medicines)

$\mathrm{I}=$ Vaccines for veterinary medicine

$\mathrm{J}=$ Medical/surgical accessories

$\mathrm{K}=$ Other products

From the following analysis (Figure 1), it can be seen that the production of pharmaceuticals, medicinal chemicals and botanicals has been growing over the years from 2013-2014 to 2018-2019, although not constantly. The trend line of the

Figure 1 Indian pharmaceutical production trends from 2013-2014 to 2018-2019

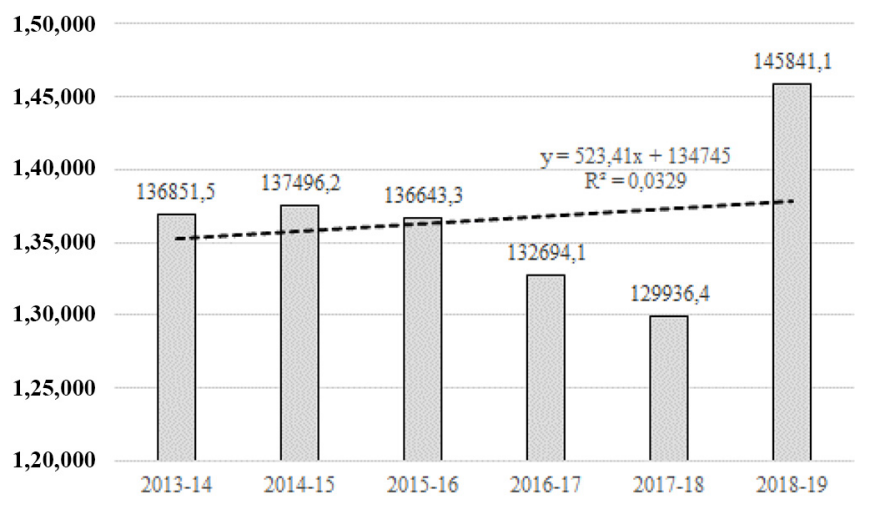

Source: Authors' calculations. Rs. millions values, derived from an ordinary least squares (OLS) calculation, shows a consistent trend regarding the increase in total production (compound annual growth rate $[\mathrm{CAGR}]=1.07 \%$ ), even though the strong impact of the 2018-2019 values is evident compared with the decreases of 2016-2017 and 2017-2018. For this reason, together with the very limited observations, the $R^{2}$ value is so low (0.0329).

These calculations allow us to respond positively to $R Q 1$ ("Are the expectations about the global value of the industry positive or negative?").

Subsequently, the trade balance of the sector was analyzed to understand the state of the art and potential development trajectories of growth/development compared to the rest of the world. The data reported in Table 2 (with the details of various categories) and Table 3 (with the related balance of the same categories) provide evidence about the progress of the Indian pharmaceutical industry and its international business.

From the following analysis (Figure 2), it can be seen that the trade balance has been growing from 2014-2015 to 2018-2019, and in this case constantly. The trend line of the values, derived from an OLS calculation, shows a consistently increasing trend in the total trade balance $(\mathrm{CAGR}=5.08 \%$ ), with reliable evidence year after year. For this reason, notwithstanding the very limited observations, the $R^{2}$ value is so high (0.8617).

With specific reference to single commercial relationships, the USA and other developed countries are major trade partners as far as exports are concerned, while India depends significantly on imports of APIs from China (Rbi.org.in). More broadly, the Indian pharmaceutical industry has major exports to North America and Europe and major imports from Asia and Europe. Furthermore, as reported in Table 4, the positive trade balance trend appears to be confirmed for the future, most likely by virtue of renewed attention of the global economies on India's pharmaceutical industry due to the COVID-19 pandemic.

From the following analysis (Figure 3), the trade balance, under the CMIE forecast, will also grow consistently along with the abovementioned trend for the years from 2015-2016 to 2023-2024. The trend line of the values, derived from an OLS calculation, shows a consistently increasing trend in the total trade balance $(\mathrm{CAGR}=4.95 \%)$, with reliable evidence year after year. For these reasons, notwithstanding the very limited observations, the $R^{2}$ value is so high (0.9678).

These calculations, as emerging from Figures 2 and 3, allow us to respond positively to $R Q 2$ ("Are the expectations about the trade balance positive or negative?"). 
Table 2 Exports and imports of the Indian pharmaceutical industry

\begin{tabular}{|c|c|c|c|c|c|c|c|c|c|c|}
\hline (Amounts in USD millions) & & & Exports & & & & & Imports & & \\
\hline Years & 2014-20 & 5 2015-2016 & 2016-2017 & 7 2017-2018 & 3 2018-2019 & 2014-2015 & 5 2015-2016 & 2016-2017 & 7 2017-2018 & 2018-2019 \\
\hline Bulk drugs, drug intermediates & 3,564 & 3,595 & 3,381 & 3,541 & 3,913 & 3,243 & 3,243 & 2,739 & 2,993 & 3,556 \\
\hline Drug formulations, biologicals & 11,211 & 12,643 & 12,660 & 12,911 & 14,406 & 1,564 & 1,583 & 1,661 & 1,842 & 2,021 \\
\hline AYUSH and herbal products & 355 & 364 & 402 & 456 & 448 & 58 & 54 & 54 & 61 & 73 \\
\hline Surgical accessories & 299 & 303 & 333 & 377 & 399 & 567 & 555 & 541 & 586 & 707 \\
\hline Total & 15,429 & 16,906 & 16,776 & 17,286 & 19,165 & 5,431 & 5,435 & 4,994 & 5,482 & 6,357 \\
\hline
\end{tabular}

Table 3 Trade balance by category of the Indian pharmaceutical industry

\begin{tabular}{|c|c|c|c|c|c|}
\hline \multirow{2}{*}{$\begin{array}{l}\text { (Amounts in USD millions) } \\
\text { Years }\end{array}$} & \multicolumn{5}{|c|}{ Trade balance (exports less imports) } \\
\hline & 2014-2015 & $2015-2016$ & 2016-2017 & 2017-2018 & 2018-2019 \\
\hline Bulk drugs, drug intermediates & 320 & 353 & 643 & 548 & 357 \\
\hline Drug formulations, biologicals & 9,648 & 11,060 & 10,999 & 11,070 & 12,385 \\
\hline AYUSH and herbal products & 297 & 310 & 348 & 395 & 375 \\
\hline Surgical accessories & -267 & -252 & -207 & -209 & -309 \\
\hline Total & 9,998 & 11,471 & 11,782 & 11,805 & 12,808 \\
\hline
\end{tabular}

Figure 2 Trade balance trends of the Indian pharmaceutical industry from 2014-2015 to 2018-2019

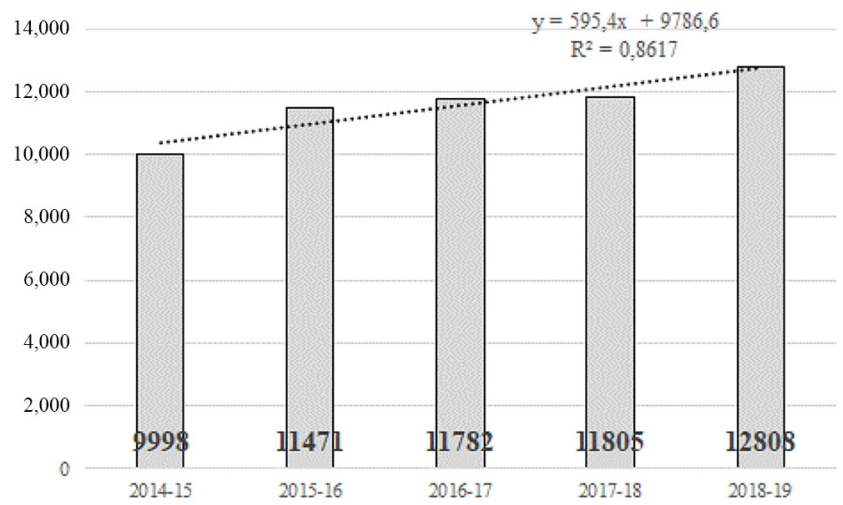

Source: Authors' calculations. USD millions

Table 4 Indian drugs exports and imports until 2018-2019 and projections thereafter

\begin{tabular}{llll}
\hline Year & Exportation & Importation & Trade balance \\
\hline 2015-2016 & $16,905.60$ & $5,434.50$ & $11,471.10$ \\
2016-2017 & $16,775.50$ & $4,993.60$ & $11,781.90$ \\
$\mathbf{2 0 1 7 - 2 0 1 8}$ & $17,286.20$ & $5,481.70$ & $11,804.50$ \\
$\mathbf{2 0 1 8 - 2 0 1 9}$ & $19,164.50$ & $6,356.90$ & $12,807.60$ \\
$\mathbf{2 0 1 9 - 2 0 2 0}$ & $20,659.90$ & $6,366.20$ & $14,293.70$ \\
$\mathbf{2 0 2 0 - 2 0 2 1}$ & $21,192.60$ & $6,576.60$ & $14,616.00$ \\
$\mathbf{2 0 2 1 - 2 0 2 2}$ & $23,002.10$ & $7,164.50$ & $15,837.60$ \\
2022-2023 & $24,336.20$ & $7,648.50$ & $16,687.70$ \\
2023-2024 & $25,853.10$ & $8,132.20$ & $17,720.90$ \\
Source: CMIE industry outlook database. USD millions \\
\hline \multicolumn{4}{l}{}
\end{tabular}

Figure 3 Trade balance trends of the Indian pharmaceutical industry until 2023-2024

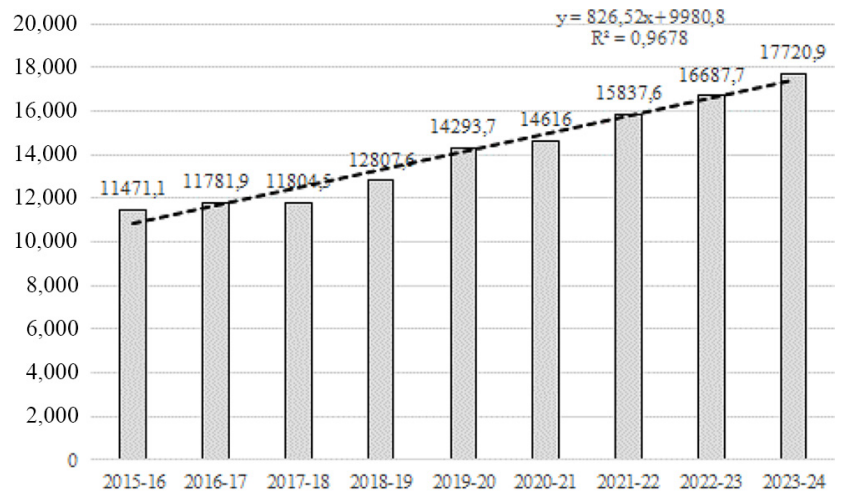

Source: Authors' analysis of CMIE forecast. USD millions

After this initial overview of the current and future situation of the Indian pharmaceutical sector, a positive picture has emerged. However, several issues cannot be highlighted by the positive numbers so far analyzed, representing weaknesses and threats for the industry that have emerged from a qualitative analysis that has been deployed to provide the basis for a subsequent narrative SWOT analysis.

\subsection{The scenario of the Indian pharmaceutical industry: contextual analysis}

Taking into consideration some of the most authoritative reports and issues in the field at the institutional and corporate levels (e.g. Biospectrum Bureau, Fortis Healthcare, IBEF, McKinsey, etc.), a content analysis was performed to identify the most relevant issues for the sector. The investigation has 
been executed manually, due to it being more sensitive than analytical, using standard office automation software for searching, retrieving, organizing, cataloging and processing the most relevant elements of the texts, focusing the attention of the global analysis on the final goal of the research, and identifying SWOT, in terms of specific words, as well as general concepts.

The most relevant results of this inquiry have been aggregated in the following seven "areas" detected by applying, after manual content analysis, the affinity diagram technique, similar to other research (Tuch et al., 2013; Zhang and Sun, 2017; Song et al., 2018). Next, the most significant evidence for each category is reported.

- Pharmaceutical research hub.

- Health-care special economic zones.

- Manufacturing facilities for medical equipment.

- Land/town planning for health-care facilities.

- Food and Drug Administration (FDA) regulations.

- Health insurance penetration.

- DPCO.

\subsubsection{Pharmaceutical research hub (potential strength)}

Innovation in the Indian pharmaceutical industry is weaker than its potential. Companies still prefer generic drug businesses and conduct less research. After the 1990s, India emerged as an information technology and information technology-enabled services hub for the world due to trained manpower, a very high number of computer engineers, and a cheaper workforce that could speak foreign languages, mostly English. Similarly, pharmaceutical research and development can be carried out in India by global pharmaceutical MNCs. India has many pharmaceutical, bioscience and chemistry colleges that churn out huge amounts of high-quality graduates every year. The skilled labor force is available in Indian cities at very competitive salaries compared to most other destinations. Having research labs in India will be a win-win situation for MNCs.

\subsubsection{Health-care special economic zones (potential opportunity)}

The medical tourism segment in the global health industry is increasing rapidly because the cost of health-care is significantly lower in India than that in Korea, Malaysia, Thailand and many other countries in the region. Improved medical facilities, modernization of hospitals and lower and affordable treatment costs for most developed and developing countries' nationals are all reasons for this boom (Fortis Healthcare, 2019).

Special economic zones (SEZs) are popular because they provide tax benefits for companies. To create new business opportunities for the pharmaceutical industry, SEZs can be a powerful option, especially if established near airports, stations and ports.

\subsubsection{Manufacturing facilities for medical equipment (potential strength)}

Currently, China is a manufacturer for the whole world. India's manpower is large, with a huge number of graduates. The earlier Indian business environment was not considered suitable for doing business, per the survey results of the International Finance Corporation (IFC.org), but in recent years, the climate has improved in terms of the ease of setting up companies, winding up, infrastructure development, etc. In India, production factors are cheaper than those in the developed world and can be associated with trained manpower. Hence, there is an opportunity to set up manufacturing facilities to produce medical equipment.

\subsubsection{Land/town planning for health-care facilities (potential opportunity)}

India has witnessed rapid population and economic growth in the past two decades, and this expansion has created a demand for larger and better infrastructure in cities and industrial parks. India's limited development of service platforms is a result of the scarce functioning of the bureaucracy, but conditions have improved in recent years. There is a need to reserve appropriate sizes of land for the health-care sector in cities and for pharmaceutical companies in industrial belts during the planning process. In India, the public health-care system is not strong, and most of the middle class and above prefer to visit private hospitals for treatment. Reservation or allocation of land for the health-care sector will boost the growth and development of the industry, resulting in employment and self-employment of health-care staff, even at the pharmaceutical level. Financially poor people use India's public health-care system and reserving land in cities for public facilities will serve the population's low-income earners.

\subsection{5 "Food and Drug Administration (FDA) regulations (potential threat)}

The USA represents a large pharmaceutical demand as companies obtain substantially higher prices for medicines sold in that market. FDA approvals are considered benchmarks across many countries; therefore, these authorizations are very important for Indian pharmaceutical industries for the access, export, presence and profit they represent at the global level. Although Indian companies have received the highest number of FDA approvals in the last decade and in 2019-2020 particularly, there is an ongoing need to obtain these authorizations. The FDA regulations are stringent and time-consuming, making it difficult for midsized Indian companies to access the North American market and other similarly developed markets. Thus, the Indian government should establish ongoing support to small- and medium-sized Indian companies in training and implementing FDA standards, as it provides easy global access to those and similar international markets.

\subsubsection{Health insurance penetration (current weakness, potential opportunity)}

The insufficient diffusion of the services associated with health insurance is a reason for pressure on prices and the slow business growth of the Indian health-care sector. Most of the population earns a very low per capita income that is considered a poverty-level wage by the standards of developed nations. In recent years, there has been some rise and subsequent awareness about health insurance, with an increase in the number of people taking health insurance policies. Many employers have started buying group health insurance policies for employees and families, but insurance coverage is still inadequate if certain medical conditions are considered.

\subsubsection{DPCO (real weakness or potential strength?)}

4.2.7.1 Influence of price controls on producers DPCO has been a drawback for drug companies because it caused a decrease in their profit margins. Developing a medicine involves many aspects and is quite costly; hence, reducing their prices and profit margins has generated complex situations for pharmaceutical companies. Drugs registered under DPCO must be sold within the price 
range, which is mandatory for the company and therefore, the break-even point is sometimes barely reached (Paul, 2018).

4.2.7.2 Influence of price controls on drug wholesalers and retailers (chemists) According to DPCO, the trade margins in the pharmaceutical supply chain should be reduced to allow better penetration of medicines under DPCO and allow a larger population to obtain access. The first-line sellers will receive different percentages of margins to apply, including distributors, wholesalers, retailers (chemists) and hospitals. If this measure proves to be successful, it will lead to a tremendous increase in the availability of essential drugs (Thacker, 2018), but at the same time, the pharmaceutical producers will have to take into careful consideration the business relationships with these operators, whose importance in the supply chain has been growing (IQVIA, 2018).

4.2.7.3 Influence of price controls on patients/consumers DPCO is a blessing for those who use medicine and has boosted their hopes of the availability of cheaper and better medicines, leading to a great psychological impact on consumers (Venkiteswaran, 2013). For example, heart attacks and cardiac arrests are increasing in India, and treatments for these newly emerging diseases are very expensive. Because open-heart surgery and the stents needed for angioplasty are not affordable to all, DPCO could offer a potential solution for these and other medical treatments (Wadhera et al., 2017).

4.2.7.4 Influence of price controls on patented drugs There was an enormous effect of price policies on brands and drugs that had similar contents. These branded drugs showed a variation in pricing, also known as inter-brand price variation. There was ample availability of multiple brands for identical drugs in India, and therefore, after DPCO was revised in 2013, a socalled tug of war between these branded drugs began. There is a concrete risk of confusion in the minds of patients/consumers regarding which drug should be considered due to this price variation. Therefore, price controls were effective at analyzing this price variation and are attempting to decrease the difference even more (Jhanwar and Sharma, 2018).

4.2.7.5 Influence of price controls on innovation management The pharmaceutical business function of $\mathrm{R} \& \mathrm{D}$ has been significantly affected by the DPCO. Due to price controls, companies have not dedicated themselves to inventing and developing new medicines. These operations need huge amounts of capital, but DPCO measures, which limit drug prices, do not contribute to establishing a favorable scenario concerning capital budgeting for R\&D. In fact, if the developed drug comes under DPCO, then it is likely that sales will be hindered, affecting the expansion of the industry due to regulations pertaining to that medicine (Biospectrum Bureau, 2016).

4.2.7.6 Influence of price controls on corporate development When the DPCO was revised, many growing pharmaceutical companies were shaken. The main reason for their slump was the establishing of prices by the government. The ceiling for drug prices placed restrictions on the companies, and because of price controls, the sales of the drugs were also hindered and therefore unsatisfactory. Other studies have confirmed that sales decreased after DPCO was revised in 2013 (Sahay and Jaikumar, 2016), with a large amount of disparity in the industry, mainly due to the rise of two dynamics: certain companies showed growth in revenue, while some companies showed a recession. Growth of companies was seen where a majority of drug prices were under the ceiling price, but in contrast, there was a decline in the growth of those companies where a majority of drug prices were above the ceiling price. Many differences were seen between DPCO and the concerned companies because of the adoption of market-based pricing (MBP). Drug prices formerly were established based on cost-based pricing, which took into consideration the different components necessary to produce a drug, including API, cost of labor and amortizations, the costs of which were used to decide on the ceiling price. However, in MBP, pricing was determined by market share, and according to demand, it was characterized into numerous categories of drugs. Thus, MBP has had an adverse impact on pharmaceutical companies (Narula, 2015).

4.2.7.7 Influence of price controls on exports and imports DPCO is applicable only in India. Consequently, domestic businesses will be hindered to some extent, and exports may blossom. Thus, focusing on specific medicines to export will probably be vital. For example, India has been universally considered the pioneer in the export market for generic drugs. In the case of other medicines, if the drug is under DPCO in India, it may be possible to sell it under price control domestically and to collect maximum revenue from exports, thus helping to enhance the country's economy (Das, 2013). Nonetheless, DPCO policies had an adverse influence on the imports of medicines to India in the form of a fall in trade due to price regulations. One of the reasons for this decrease was the transition of the pricing strategy from cost-based to marketbased policies, a noticeable cause due to the implications deriving from DPCO (PTI, 2013).

4.2.7.8 Positive and negative effects of price controls A rise in the profit margin of businesses having product prices below DPCO was registered, which resulted in economies of scale (Venugopal and Jampala, 2019). The expenditure on health care in India has ultimately reduced the costs of medicines under DPCO, and essential drugs are coming under the ceiling price every day (Kuchey and Jan, 2018). Therefore, a better distribution of medicine in the middle-income groups, who need medicines for several treatments, has been observed. There was social and economic injustice because the low- and middle-income classes could not afford costly medicines, and DPCO resulted in socioeconomic justice for many poor people in India, a developing country. However, pharmaceutical companies may lose interest in the Indian market due to the fixation of prices, which can lead to economic uncertainty since the Indian market is under rigorous pricing laws (Kumar et al., 2020). Another major concern is that medicines are not available where needed due to an inadequate supply chain and to the absence of potential producers that may not be attracted by these restrictions. If there is a lack of proper supply of medicine to the needy, this would be in contradiction with the objectives of social justice (Mrinali, 2013). Thus, the Indian government should take effective measures to better balance the positive and negative effects of DPCO.

\section{A narrative strengths, weaknesses, opportunities and threats analysis of the Indian pharmaceutical industry}

After developing the above topics, it is possible to implement a potential framework to oversee the current and future conditions 
of the Indian pharmaceutical industry. Naturally, the peculiar situation is considered due to the COVID-19 pandemic, whose impact in the near and far future may greatly influence scenario analysis. For these reasons, we opted for a narrative SWOT analysis, similar to other studies (Vandevelde and Halleux, 2017; Septinaningrum and Nugraha, 2019; Cowx et al., 2010).

\subsection{Strengths}

There is a robust low-cost manufacturing setup available in India, where the industry can produce drugs at a cost that is $40 \%-50 \%$ lower than the rest of the world and sometimes even as much as $90 \%$. There is also a presence of good technical and technological expertise together with the availability of low-cost skilled human resources. Moreover, the penetration of modern medicine in India is less than $30 \%$. Hence, there is a large untapped market available. The growth of the middle-class population is leading to a new lifestyle, providing a huge market for lifestyle drugs, which are currently the lowest contributor to revenues from the sector. The industry possesses excellent chemistry and process reengineering skills. This provides an added advantage to the nation, which assists in developing processes that are cost-effective (Mahajan, 2019).

Another strength concerns the AYUSH market. As previously mentioned, the AYUSH Ministry was formed in 2014 for the development and spread of Ayurveda, Yoga and Naturopathy, Unani, Siddha and Homoeopathy treatments. Earlier, it was known as the Department of Indian System of Medicine and Homeopathy (ISM\&H), founded in 1995. In addition to modern medicine, Ayurveda and the other mentioned treatments are highly popular in India. Patanjali, Himalaya, Vicco Laboratories and Dabur are the major companies manufacturing in the field (Mehrotra et al., 2017). Due to the greater effectiveness of modern medicine, Ayurveda has been losing its importance from a technological point of view, although during the period from 2014-2015 to 2018-2019, AYUSH treatments have seen significant growth in production and exportation, as was seen from the data provided above, and the AYUSH Ministry is spreading awareness of immunity-boosting using AYUSH remedies with reference to COVID-19 (Chaturvedi et al., 2020; Priya and Sujatha, 2020; Ayush.gov.in). Although there seems to be even less demand for these treatments in a reasonable future in comparison to modern medicine, the AYUSH field still attracts investments (Joshi and Srivastava, 2013), and companies engaged in this specific subsector of the Indian pharmaceutical industry will probably see higher exports, in part because there is governmental support. Indian companies engaged in AYUSH production and distribution will have to consider a long-term perspective; in the near future, positive results are likely, but in long-range planning, with the tremendous increase of technology, focusing on this segment could be very risky. In fact, AYUSH represents a mass-niche market, requiring peculiar attention mostly in terms of competitive strategies that would have a focus orientation.

\subsection{Weaknesses}

There is less emphasis on $\mathrm{R} \& \mathrm{D}$ in pharmaceuticals, which have a major focus on generics. This is because in India, there is an inadequate $\mathrm{R} \& \mathrm{D}$ infrastructure and lower industry-academia connection for research. As mentioned above, DPCO establishes the various pricing parameters according to which the price is to be decided, and this policy reduces the profitability of the companies that would invest in innovative drugs, which requires huge capital. This sector has been hamstrung by a lack of product patents, due to which foreign companies do not introduce new drugs in the Indian market, discouraging innovation and drug discovery. Paradoxically, low entry barriers have led to fragmented industries that make the sector highly accessible due to competition (Mahajan et al., 2018).

\subsection{Opportunities}

There are a large number of drugs that went off patents, providing many pharmaceutical companies with huge opportunities to enter the market. India is a country where good skills are available at a lower cost, thus it is emerging as an attractive destination for contract research and manufacturing organizations due to rapid growth of the domestic market, robust foreign direct investment (FDI) policies (which are attracting large amounts of green-field and brown-field investments in production and capacity-building from MNCs) and steady (although not so quick) migration to a product patent-based regime. The increased inclination toward the health insurance sector and the growth of per capita income have expanded the purchasing capacity of patients/consumers, providing a long-term perspective for the development of the pharmaceutical sector. Hence, India can become a global outsourcing hub for pharmaceutical products due to its lowcost production ability combined with FDA-approved manufacturing plants (Vaidya et al., 2018).

\subsection{Threats}

In the present scenario, the changes in the patent regime may benefit MNCs, while domestic companies may face more challenges. Similarly, the threats possibly deriving from other low-cost countries - China above all - are real. The negotiations with MNCs, international rules and domestic regulations are imbalanced, while there are increasingly stringent regulations and nontariff barriers to generic drugs in developed countries (Dhar and Joseph, 2019).

Taking into account the above considerations, from a narrative and then qualitative point of view, a positive scenario for the Indian pharmaceutical industry can be highlighted, thus providing a response to $R Q 3$ ("What are the most relevant SWOT for the future?"). More specifically, both attack and defense strategies have emerged at the same time. For example, an attack strategy seems realistic when combining strengths such as the industry's manufacturing ability and the rising economy of the country, thinking about a competitive strategy based on differentiation and/or niche orientation for innovative and patented drugs. Similarly, a defense strategy seems realistic when combining the experience with generic drug production with DPCO limits, thinking about a competitive strategy based on cost leadership, which may be sustainable considering the huge population of the country.

\section{Theoretical and practical implications}

The study seems to have an impact in at least three areas: growth of the sector, growth drivers and human capital in the patent-based regime. All have been associated with relevant implications. 


\subsection{Growth of the sector}

The Indian pharmaceutical industry has been living a situation of constant growth in recent years, as shown by statistical analyses of the field at the descriptive and inferential levels. There are increased expectations regarding both the production amount and the trade balance value.

Although the sector must tackle several issues concerning internal (fragmented) and external (innovative) competition, drug price controls and patent regimes have a significant influence on its effective functioning, which is why the Indian pharmaceutical industry is still mainly concentrated on generic drugs. Although some Indian companies have invested significantly in R\&D initiatives, most of them prefer remaining in the business of generic drugs. Because it does not require huge efforts to invent new molecules, there are still numerous small companies that produce the same generic drugs, creating tough competition in the domestic market (Pardhe, 2019).

Nonetheless, despite being a global market leader in generic drug formulations, the Indian pharmaceutical industry is highly dependent on China for raw material supply to produce pharmaceutical formulations and even medicines. India imports approximately $70 \%$ of its raw materials from China (Shreyan, 2020).

Thus, from a practical point of view, it is expected that entrepreneurs, managers, and professionals in the field would also orient their attention mostly on innovative and patented drugs to avoid dangerous competition based on low prices if possible, establishing alliances for legally influencing the government with forward-looking lobbying. From a theoretical point of view, there is a need to analyze and develop innovative strategies in "transition," which could assist companies in sustaining their financial performance based on the positive outlook that emerged from the field investigation, with a farsighted perspective at the national and international levels.

\subsection{Growth drivers}

In coming years, per capita health-care expenditures in India will grow exponentially, especially because of the higher penetration of health-care services and increasing spending capacity of the population (Dogra and Dogra, 2018). Other influencing factors are governmental initiatives to support, the intensification of R\&D investments, and the expansion of foreign investments (Ganesan and Veena, 2018). This situation also affects the pharmaceutical industry, particularly with the following features:

- The growing investment in $\mathrm{R} \& \mathrm{D}$ is a driving factor, together with mergers \& acquisitions; Indian pharmaceutical companies invested approximately $9 \%$ of their revenues in R\&D during 2018 (DIPP, 2018), while in 2017, there were 46 deals for US $\$ 1.47 \mathrm{bn}$ in India's pharmaceutical industry (Dhingra, 2019).

- The low cost of production may support companies' competitiveness, contributing to profitable exports: the production cost in India is much lower than that in the USA, and thus India's capacity to produce high-quality and low-priced medicines represents an enormous business opportunity for the global and domestic industry (ICRA, 2019).

- To support economic growth, it is necessary to improve medication affordability and increase health insurance coverage, boosting spending on health-care in general and more specifically on medicine; in rural India in particular, special attention must be paid to over-the-counter drugs (IBEF, 2019).

- The Pharma Vision 2020 is the governmental project for assisting the global expansion of the industry to make India a world leader in end-to-end production of drugs, with huge investments by the Ministry of Health and Family Welfare; additionally, there is a favorable propensity for FDI in the sector under the automatic route.

- India ranks among the industry leaders in clinical trials, having the availability of genetically diverse populations and qualified health-care professionals; moreover, the Contract Research and Manufacturing Services industry in India is projected to hit US $\$ 20$ bn by 2020 (McKinsey, 2020).

Thus, from a practical point of view, Indian pharmaceutical companies are somehow forced to continue to leverage their expertise in generic drugs, considering the positive financial impact of these productions. At the same time, according to an ambidextrous perspective, they should try to invest in R\&D for innovative drugs to capture new opportunities arising from the demands for good health from the growing income classes. From a theoretical point of view, major attention should be paid to conceiving innovative formulas of collaborations at the private and public-private levels, given the rising weight of private companies in the field, and establishing correct and forward-looking alliances for the development of the sector at the national and international levels.

\subsection{Human capital in the patent-based regime}

In India, the IPR regime is important at all levels - statutory, administrative, and judicial. Starting in 1995, an agreement on Trade Related Aspects of Intellectual Property Rights (TRIPS) was established after negotiation with the World Trade Organization, defining the minimum standards for the protection and enforcement of IPRs in member countries.

Several factors have an impact on pharmaceutical patents in India, such as an increasing level of income, a consistent growth rate of the domestic economy, and rapid growth in the diffusion of better economic conditions. In this respect, however, foreign companies, as well as national companies, have been reluctant to invest in R\&D in India (Ghai, 2010). Indeed, compared to developed nations, Indian pharmaceutical companies concentrate less on innovation, where they allocate less budget. For all the above-described reasons, they find manufacturing generic drugs more lucrative, as the outcome is guaranteed. Consequently, although India produces a large number of graduates, due to a lack of enthusiasm from the companies for $\mathrm{R} \& \mathrm{D}$, they press to change professions or tend to perceive careers in related areas because the average remuneration in pharmaceutical companies is less than that in other industries (Schweitzer and Lu, 2018).

Thus, from a practical point of view, Indian pharmaceutical companies should invest more in $\mathrm{R} \& \mathrm{D}$, attempting to attract talented human capital. Otherwise, they will lose the highly qualified national workforce that will favor MNCs in the field. From a theoretical point of view, the contribution of intellectual capital to the financial stability and economic prosperity of the 
pharmaceutical industry, most of all due to patents as immaterial assets deriving from human, structural and/or relational capital, seems indispensable (Festa et al., 2020).

\section{Research limitations and future directions}

The principal aim of this study is to conduct an explorative investigation of the current and future situation of the Indian pharmaceutical industry, with the development of a narrative SWOT analysis to generate an overall scenario analysis. The empirical inquiry has been fundamentally based on secondary data, at the descriptive and inferential levels, limiting, due to constraints concerning the volume of the calculations, the years under observation (six years for the total production value, five years for the total trade balance and nine years for the total trade balance projections). This is the first limitation of the research, thus, further investigations expanding the range of the data under examination would improve the reliability of the results.

However, the most critical limitation seems to concern the content analysis that has enabled the elaboration of the SWOT analysis, particularly concerning the choice of the institutional reports and issues under investigation and the possible methods of examination. Further research involving other reports and even interviews with experts could mitigate this limitation, researching more numerous, shared, qualified and reliable content and adopting more methods.

\section{Conclusion}

The production of pharmaceuticals, medicinal chemicals and botanicals for health-care has been growing yearly in India. Particularly, the country exports generic medicines on a large scale, with a major impact in the American and European markets.

The infrastructure of the industry and the R\&D capabilities of domestic businesses have improved considerably in recent years, but many challenges remain, mainly related to pricing regulation, sector fragmentation and intellectual property. Not surprisingly, all of them, directly or indirectly, concern patents, which are central issues of debate in the national industry.

Nevertheless, India has a massive population with low per capita income, and stricter patent rules would probably mean less access to medicine for a significant part of the population. The affordability of pharmaceuticals is a critical challenge in India and South Asia in general, raising questions of life and death.

Finally, the study has revealed in a current and future scenario analysis that the overall situation of the Indian pharmaceutical industry is positive at the economic, business and commercial levels, even though with many concerns. Most likely, however, the real challenge of the sector will entail a sustainable compromise between the legitimate expectations of innovative growth from the business point of view and the fundamental exigencies of affordable health from a social point of view.

\section{References}

Abbott, F.M. (2017), "Indian policies to promote local production of pharmaceutical products and protect public health", World Health Organization, pp. 3-17, available at: www.who.int/phi/publications/2081India020517.pdf (last access 15 January 2021).
Abrol, D., Prajapati, P. and Singh, N. (2011), "Globalization of the Indian pharmaceutical industry: implications for innovation", International fournal of Institutions and Economies, Vol. 3 No. 2, pp. 327-365.

Bains, P., Singh, T. and Singh, A. (2010), "Status of home based care provision to bedridden elderly in Chandigarh", Fournal of the Indian Academy of Geriatrics, Vol. 6 No. 2010, pp. 9-13.

Biospectrum Bureau (2016), "DPCO: a nightmare for pharma firms?", available at: www.biospectrumindia.com/features/ 73/7663/dpco-a-nightmare-for-pharma-firms-.html (last access 15 January 2021).

Chattopadhyay, S., Bercovitz, J. (2020), "When one door closes, another door opens... for some: evidence from the post-TRIPS Indian pharmaceutical industry", Strategic Management fournal, Vol. 41 No. 6, pp. 988-1022.

Chaturvedi, S., Kumar, N., Tillu, G., Deshpande, S. and Patwardhan, B. (2020), "AYUSH, modern medicine and the Covid-19 pandemic", Indian fournal of Medical Ethics, Vol. 5 No. 3, pp. 1-4.

Chaudhuri, S.K. (2019), "Patents on medical innovations and value pluralism in India: paradoxes and choices", Asian Biotechnology and Development Review, Vol. 21 No. 3, pp. 41-81.

Cowx, I.G., Arlinghaus, R. and Cooke, S.J. (2010), "Harmonizing recreational fisheries and conservation objectives for aquatic biodiversity in inland waters", fournal of Fish Biology, Vol. 76 No. 9, pp. 2194-2215.

Das, S. (2013), "DPCO impact: revenue of local pharma players", available at: www.business-standard.com/article/ companies/dpco-impactrevenue-of-local-pharma-players-maydip-113070101023_1.html (last access 15 January 2021).

de Kluyver, C.A. (1980), "Bottom-up sales forecasting through scenario analysis", Industrial Marketing Management, Vol. 9 No. 2, pp. 167-170.

Desai, J. and Desai, R. (2018), "Financing decision as a determinant of firms' performance: Indian pharmaceutical industry", SCMS fournal of Indian Management, Vol. 15 No. 3, pp. 20-28.

Devarakonda, S. (2016), "Hub and spoke model: making rural healthcare in India affordable, available and accessible", Rural and Remote Health, Vol. 16 No. 1, pp. 1-8.

Dhar, B. and Joseph, R.K. (2019), "The challenges, opportunities and performance of the indian pharmaceutical industry Post-TRIPS", in Liu, K.-C. and Racherla, U. (Eds), Innovation, Economic Development, and Intellectual Property in India and China, Singapore, Springer, pp. 299-323.

Dhingra, K. (2019), "An analysis of mergers and acquisitions in Indian pharmaceutical industry", Amity Global Business Review, Vol. 1 No. 2019, pp. 72-83.

Dogra, A.K. and Dogra, P. (2018), "The medical tourism industry in the BRIC nations: an Indian analysis", in Dhiman, M.C. (Ed.), Opportunities and Challenges for Tourism and Hospitality in the BRIC Nations, Hershey, PA, USA, IGI Global, pp. 320-336.

Festa, G., Rossi, M., Kolte, A. and Marinelli, L. (2020), "The contribution of intellectual capital to financial stability in Indian pharmaceutical companies", Fournal of Intellectual Capital, Vol. 22 No. 2, pp. 1-23, doi: 10.1108/JIC-03-2020-0091.

FICCI (2018), "Trends \& opportunities for Indian pharma", White Paper, pp. 1-24, available at: http://ficci.in/spdocument/ 
22944/india-pharma-2018-ficci.pdf (last access 15 January 2021).

Fortis Healthcare (2019), "2018-19 Annual report analysis", available at: www.equitymaster.com/research-it/annualresults-analysis/FORTIS/FORTIS-HEALTHCARE-201819-Annual-Report-Analysis/815 (last access 15 January 2021).

Ganesan, L. and Veena, S.R. (2018), “'Make in India' for healthcare sector in India: a SWOT analysis on current status and future prospects", International fournal of Health Sciences and Research, Vol. 5 No. 1, pp. 70-76.

Gautam, A. and Sharma, S. (2019), "Two way analysis of GST: with reference to healthcare and pharma sector", Indian Fournal of Public Health Research \& Development, Vol. 10 No. 1, pp. 151-155.

Ghai, D. (2010), "Patent protection and Indian pharmaceutical industry", International fournal of Pharmaceutical Sciences Review and Research, Vol. 3 No. 2, pp. 43-48.

Guercini, S., Milanesi, M. and Runfola, A. (2020), "Bridges to sustainable health systems: public-private interaction for market access", fournal of Business \& Industrial Marketing, Vol. 35 No. 12, pp. 1929-1939.

Gulaldavar, N.B. (2019), "USFDA announcement reaction on Indian pharma companies share prices-A test of efficient market hypothesis through event study methodology", International fournal of Research in Social Sciences, Vol. 9 No. 2, pp. 554-566.

Ha, B.-C. and Nam, H. (2016), "Ethical judgments in supply chain management: a scenario analysis", fournal of Business E् Industrial Marketing, Vol. 31 No. 1, pp. 59-69.

IBEF (2016), "Healthcare", pp. 1-49, available at: www.ibef. org/download/Healthcare-September-2016.pdf (last access 15 January 2021).

IBEF (2019), "Pharmaceuticals", pp. 1-33, available at: www. ibef.org/download/Pharmaceuticals-July-2019.pdf (last access 15 January 2021).

IBEF (2020), "Indian pharmaceuticals industry report", available at: www.ibef.org/industry/indian-pharmaceuticalsindustry-analysis-presentation\#sthash.qPWNb7FZ.dpuf (last access 15 January 2021).

ICRA (2019), "Indian pharma to grow at 11-13\% in FY2020", pp. 1-3, available at: www.icra.in/Media/OpenMedia?Key= 1ec9eaff-9659-48f2-b796-693fca30e4ca (last access 15 January 2021).

IQVIA (2018), "Winning in the Indian pharmaceutical market”, White Paper, available at: www.iqvia.com/-/media/ iqvia/pdfs/india/winning-in-the-indian-pharmaceutical-market. pdf? $=1610873724999$ (last access 15 January 2021).

Jhanwar, A. and Sharma, N. (2018), "Cost analysis and price variation of commonly used drugs in obstetrics and gynecology in Jhalawar district of Rajasthan, India", International fournal of Basic E Clinical Pharmacology, Vol. 7 No. 8, pp. 1537-1541.

Joshi, M. and Srivastava, A. (2013), "I have a dream: ayuvayur pharmaceuticals", Emerald Emerging Markets Case Studies, Vol. 3 No. 1, pp. 1-10.

Kirchgeorg, M., Jung, K. and Klante, O. (2010), "The future of trade shows: insights from a scenario analysis", fournal of Business $\mathcal{E}$ Industrial Marketing, Vol. 25 No. 4, pp. 301-312.
Kraus, S., Schiavone, F., Pluzhnikova, A. and Invernizzi, A.C. (2021), "Digital transformation in healthcare: analyzing the current state-of-research", Fournal of Business Research, Vol. 123, pp. 557-567.

Kuchey, A.A. and Jan, A. (2018), "Indian pharmaceutical industry regulation and supervision: issues and practices", Arabian fournal of Business and Management Review (Oman Chapter), Vol. 7 No. 4, pp. 104-110.

Kumar, A., Soni, R., Hawaldar, I.T., Vyas, M. and Yadav, V. (2020), "The testing of efficient market hypotheses: a study of Indian pharmaceutical industry", International fournal of Economics and Financial Issues, Vol. 10 No. 3, pp. 208-216.

Lee, M. and Choi, M. (2015), "The determinants of research and development investment in the pharmaceutical industry: focus on financial structures", Osong Public Health and Research Perspectives, Vol. 6 No. 5, pp. 302-309.

Lepore, L., Metallo, C., Schiavone, F. and Landriani, L. (2018), "Cultural orientations and information systems success in public and private hospitals: preliminary evidences from Italy", BMC Health Services Research, Vol. 18 No. 1, pp. 1-13.

Lew, C., Meyerowitz, D. and Svensson, G. (2019), "Formal and informal scenario-planning in strategic decision-making: an assessment of corporate reasoning", fournal of Business $\mathcal{E}$ Industrial Marketing, Vol. 34 No. 2, pp. 439-450.

McKinsey (2020), "India pharma 2020 propelling access and acceptance, realising true potential", pp. 1-29, available at: www.mckinsey.com/ /media/mckinsey/dotcom/client_service/ Pharma\%20and\%20Medical\%20Products/PMP\%20NEW/ PDFs/778886_India_Pharma_2020_Propelling_Access_and_ Acceptance_Realising_True_Potential.ashx (last access 15 January 2021).

Mahajan, V. (2019), "Structural changes and trade competitiveness in the Indian pharmaceutical industry in product patent regime", International fournal of Pharmaceutical and Healthcare Marketing, Vol. 13 No. 1, pp. 21-39.

Mahajan, V., Nauriyal, D.K. and Singh, S.P. (2018), "Efficiency and its determinants: panel data evidence from the Indian pharmaceutical industry", Margin: The fournal of Applied Economic Research, Vol. 12 No. 1, pp. 19-40.

Mehrotra, S., Salunkhe, U. and Chakraborty, I. (2017), "Patanjali: an Indian FMCG on growth path", Emerald Emerging Markets Case Studies, Vol. 7 No. 2, pp. 1-35.

Mrinali, M. (2013), "The critical analysis of new drugs pricing policy: pros and cons", available at: www.mondaq.com/ india/ $\mathrm{x} / 231726 / \mathrm{Life}+$ Sciences + Biotechnology/The + Critical + Analysis + Of + The + New + Drugs + Pricing + Policy + Pros + And + Cons (last access 15 January 2021).

Nalinakanthi, V. (2014), "All you wanted to know about: DPCO", available at: www.thehindubusinessline.com/opinion/ Allyou-wanted-to-know-about-DPCO/article20876551.ece (last access 15 January 2021).

Narula, S. (2015), "Current drug pricing status in India", Pharmacoeconomics: Open Access, Vol. 1 No. 1, p. 1.

Parasiya, S., Balamuralidhara, V., Kumar, P., Dave, A., Gujrati, R. and Shukla, A. (2013), "Need for drug price control in India", International fournal of Drug Regulatory Affairs, Vol. 1 No. 4, pp. 12-18.

Pardhe, S.P. (2019), "A descriptive cross-sectional study to evaluate the generic drug user fee act: a boon or loss to the 
Indian generic pharmaceutical industry", fournal of Applied Pharmaceutical Science, Vol. 9 No. 2, pp. 44-51.

Paul, S. (2018), "Impact on the pharmaceutical industry after NPPA fixed the price for 92 drug formulations", available at: https://health.economictimes.indiatimes.com/news/pharma/ impact-on-the-pharmaceutical-industry-afternppa-fixed-theprice-for-92-drug-formulations/66216610 (last access 15 January 2021).

Pilon, F. and Hadjielias, E. (2017), "Strategic account management as a value co-creation selling model in the pharmaceutical industry", fournal of Business \& Industrial Marketing, Vol. 32 No. 2, pp. 310-325.

Pinchot, G. III, (2001), "The need for accountability: control and the industrial marketer", in Morris, M.H., Pitt, L.F. and Honeycutt, E.D. (Eds), Business-to-Business Marketing: A Strategic Approach, Thousand Oaks, CA, USA, Sage, pp. 471-506.

Prakash, A., Sarma, P., Kumar, S. and Medhi, B. (2018), "Intellectual property rights and Indian pharmaceutical industry: present scenario", Indian fournal of Pharmacology, Vol. 50 No. 2, pp. 57-60.

Priya, R. and Sujatha, V. (2020), "AYUSH for COVID-19: science or superstition?", Indian fournal of Public Health, Vol. 64 No. 6, pp. 105-107.

PTI (2013), "DPCO may impact domestic revenue of pharma companies in 2014: Dun \& Bradstreet”, available at: https:// economictimes.indiatimes.com/industry/healthcare/biotech/ pharmaceuticals/dpco-may-impact-domestic-revenue-ofpharma-companies-in-2014-dun-bradstreet/articleshow/ 28092710.cms (last access 15 January 2021).

Roy, J., Kolte, A., Sangvikar, B. and Pawar, A. (2019), "Accessing the equity return volatility effect of east and South Asian nations: the econometrics modelling method", International fournal of Recent Technology and Engineering, Vol. 8 No. 3S, pp. 594-603.

Sahay, A. and Jaikumar, S. (2016), "Does pharmaceutical price regulation result in greater access to essential medicines?", Indian Institute of Management Ahmedabad (India) White Paper No. 2016-02-01, pp. 1-28, available at: https://web. iima.ac.in/assets/snippets/workingpaperpdf/221751251 2016-02-01.pdf (last access 15 January 2021).

Sampat, B.N. and Shadlen, K.C. (2017), "Secondary pharmaceutical patenting: a global perspective", Research Policy, Vol. 46 No. 3, pp. 693-707.

Sampath, P.G. (2006), "Indian pharma within global reach?", United Nations University - Maastricht Economic and Social Research Institute on Innovation and Technology (MERIT) Working Paper 2006-031, pp. 1-44, available at: www.merit.unu.edu/publications/wppdf/2006/wp2006-031. pdf (last access 15 January 2021).

Santos, J.N., Mota, J. and Baptista, C.S. (2019), "The role of a strategic net in international entrepreneurship: overcoming the liabilities of foreignness and outsidership in the context of the pharma industry", International Entrepreneurship and Management fournal, Vol. 17 No. 1, pp. 1-20.

Schiavone, F. and Simoni, M. (2019), "Strategic marketing approaches for the diffusion of innovation in highly regulated industrial markets: the value of market access", Fournal of Business \& Industrial Marketing, Vol. 34 No. 7, pp. 1606-1618.
Schweitzer, S.O. and Lu, Z.J. (2018), Pharmaceutical Economics and Policy: perspectives, Promises, and Problems, Oxford, UK, Oxford University Press.

Septinaningrum, A., M. and Nugraha, L. (2019), "An analysis of multicultural values actualization in grebeg pancasila rite", Blitar, East Fava, the 4th International Seminar on Social Studies and History Education Proceedings, 5 November 2019, Pendidikan Universitas Indonesia, Bandung (Indonesia), pp. 507-521.

Sharma, C. (2016), "R\&D, technology transfer and productivity in the Indian pharmaceutical industry", International fournal of Innovation Management, Vol. 20 No. 1, pp. 1-24.

Shreyan, M.L. (2020), "Indian API industry has the tide turned?", Fournal of Generic Medicines: The Business fournal for the Generic Medicines Sector, Vol. 16 No. 1, pp. 27-38.

Singh, Y. (2017), "Drug price control in India", available at: www.jagranjosh.com/current-affairs/drug-price-control-inindia-1487586858-1 (last access 15 January 2021).

Song, S., Saito, H. and Kawamura, H. (2018), "Content analysis of travel reviews: Exploring the needs of tourists from different countries", in Stangl, B. and Pesonen, J. (Eds), Information and Communication Technologies in Tourism 2018, Cham, Switzerland, Springer, pp. 93-105.

Thacker, T. (2018), "NITI aayog backs cap on pharma trade margins", available at: www.livemint.com/Industry/ 1wpipcSFnhzNDhf03XNVUP/NITI-Aayogbacks-cap-onpharma-trade-margins.html (last access 15 January 2021).

Tuch, A.N., Trusell, R. and Hornbæk, K. (2013), “Analyzing users' narratives to understand experience with interactive products", The Conference on Human Factors in Computing Systems Proceedings, 27 April - 2 May 2013, Paris (France), pp. 2079-2088.

Tyagi, S. and Nauriyal, D.K. (2017), "Firm level profitability determinants in Indian drugs and pharmaceutical industry", International Fournal of Pharmaceutical and Healthcare Marketing, Vol. 11 No. 3, pp. 271-290.

Tyagi, S., Nauriyal, D.K. and Gulati, R. (2018), "Firm level $\mathrm{R} \& \mathrm{D}$ intensity: evidence from Indian drugs and pharmaceutical industry", Review of Managerial Science, Vol. 12 No. 1, pp. 167-202.

Vaidya, M., Garg, S., Singh, C. and Mahajan, M.M. (2018), "Changing dimensions of drug patents of Indian pharmaceutical industry", fournal of Intellectual Property Rights, Vol. 24 No. (2018), pp. 111-118.

Vandevelde, K. and Halleux, I. (2017), "Assessing HRS4R applications under the strengthened procedure", University of Liege Webinar White Paper, pp. 1-23, available at: https://orbi. uliege.be/handle/2268/215415 (last access 15 January 2021).

Venkatesh, U., Mogan, K.A., Kumar, M., Doley, P. and Kishore, J. (2019), "Ayushman Bharat is a boon for the country: for the motion", International fournal of Preventive, Curative $\mathcal{G}$ Community Medicine, Vol. 5 No. 3, pp. 31-35.

Venkiteswaran (2013), "Can the new drug price control order 2013 make medicine cheaper and more affordable?", available at: www.indiastudychannel.com/resources/160716Can-new-Drug-Price-Control-Order-2013-makemedicinecheaper-more.aspx (last access 15 January 2021). 
Venugopal, P.R. and Jampala, R.C. (2019), "Impact of dividend policy on share prices: a study on select Indian pharma companies", fIMS8M: The fournal of Indian Management E Strategy, Vol. 24 No. 2, pp. 4-11.

Vijayalakshmi, V. and Srividya, M. (2015), "A study on working capital management of pharmaceutical industry in India”, fournal of Management and Science, Vol. 5 No. 3, pp. 2249-1260.

Wadhera, P., Alexander, T. and Nallamothu, B.K. (2017), "India and the coronary stent market: getting the price right”, Circulation, Vol. 135 No. 20, pp. 1879-1881.

Waluszewski, A., Hakansson, H. and Snehota, I. (2019), "The public-private partnership (PPP) disaster of a new hospital expected political and existing business interaction patterns”, Fournal of Business \& Industrial Marketing, Vol. 34 No. 5, pp. 1119-1130.

Wankhar, D.L. (2015), "Indian economic service", available at: www.arthapedia.in/index.php?title=Drug_Price_Control_ Orders_(DPCO) (last access 15 January 2021).

Zhang, L. and Sun, X. (2017), "Can travel information websites do better? Facilitating the Decision-Making experience for tourists", in Yamamoto, S. (Ed.), Human Interface and the Management of Information: Supporting Learning, Decision-Making and Collaboration. HIMI 2017. Lecture Notes in Computer Science, Cham, Switzerland, Springer, Vol. 10274, pp. 302-313.

Zhang, Y., Zhang, L., Zhang, X., Yang, M.M., Zhang, S., Li, S.-J. and Huang, Y.-Y. (2018), "Hospital service quality and patient loyalty: the mediation effect of empathy", foumal of Business E Industrial Marketing, Vol. 33 No. 8, pp. 1176-1186.

Ayush.gov.in Cmie.com

Ifc.org

Imf.org

Rbi.org.in

Who.int

\section{About the authors}

Giuseppe Festa Associate Professor of Management, Department of Economics and Statistics, University of Salerno (Italy), gfesta@unisa.it Giuseppe Festa is the corresponding author and can be contacted at: gfesta@unisa.it Giuseppe Festa is an Associate Professor of Management at the Department of Economics and Statistics of the University of Salerno, Italy, EU. He holds a $\mathrm{PhD}$ in Economics and Management of Public Organizations from the University of Salerno, where he is the former Scientific Director of the
Postgraduate course in Wine Business and the Vice-Director of the Second Level Master's in Management of Healthcare Organizations - Daosan. He is also the Chairman of the Euromed Research Interest Committee on Wine Business. His research interests focus mainly on wine business, information systems and healthcare management. Giuseppe Festa is the corresponding author and can be contacted at: gfesta@unisa.it

Ashutosh Kolte Associate Professor of Finance, Department of Management Sciences, Savitribai Phule Pune University (India), ashutoshkolte@gmail.com

Ashutosh Kolte is an Associate Professor of Finance and Economics at the Department of Management Sciences (PUMBA), Savitribai Phule Pune University, Pune, India. He was Postdoctoral Fellow at University of Sannio, Italy. He has research interest in the area of Corporate Finance, Economics, and Financial Management. He sits in the editorial board of "International Journal of Globalisation and Small Business" and acts as referee for many international journals.

Maria Rosaria Carli Senior Researcher, Institute for Studies on the Mediterranean (ISMed), Italian National Research Council (CNR), carli@ismed.cnr.it

Maria Rosaria Carli was formerly Director of the Institute of Research on Mediterranean Economies of Italian CNR. Her research interests are focused on Economics of Development and she was Adjunct Professor of Economics of Developing Countries at the "Parthenope" University of Naples, Italy. She was Italian member of the Core Group and Standing Committee for the Social Sciences - European Science Foundation. She is scientific coordinator for the CNR on R\& $\mathrm{D}$ projects and has published articles on national and international journals, as well as essays on collective volumes.

Matteo Rossi Associate Professor of Corporate Finance, Department of Law Economics Management and Quantitative Methods, University of Sannio, Benevento (Italy) and Wyzsza Szkoła Bankowa w Poznaniu - WSB University in Poznan (Poland), mrossi@unisannio.it

Matteo Rossi received the $\mathrm{PhD}$ degree in Management from the University of Sannio, Benevento, Italy. He is currently an Associate Professor of Corporate Finance at the University of Sannio, Benevento, Italy. $\mathrm{He}$ is also an Adjunct Professor of Advanced Corporate Finance at LUISS, Rome, Italy. He is the Editor-in-Chief for the International Journal of Managerial and Financial Accounting and for the International Journal of Behavioral Accounting and Finance. 